\title{
The Impact of Investment in Human Capital on Bank Performance: Evidence from Bangladesh
}

\section{Bilkis Akhter}

Dhaka University

Md. Mominur Rahman ( $\nabla$ mominurcou@gmail.com )

Comilla University https://orcid.org/0000-0001-5726-6123

\section{Research Article}

Keywords: Human capital, Human capital investment, Bank performance, Janata Bank Limited, SEM

Posted Date: February 22nd, 2021

DOl: https://doi.org/10.21203/rs.3.rs-261442/v1

License: (c) (i) This work is licensed under a Creative Commons Attribution 4.0 International License. Read Full License 


\title{
The Impact of Investment in Human Capital on Bank Performance: Evidence from Bangladesh
}

\begin{abstract}
The objective of this study is to examine the aspects of investment in human capital like training of employees, education level of employees, knowledge level of employees, and skills of employees that influence the performance of a bank and to provide some comments to improve the banking sectors. This research included a conceptual model along with hypotheses. This empirical study is based on primary data. The data were obtained by the convenient sampling procedure with a questionnaire using the Seven Point Likert Scale. The hypothesized model has been validated using data from 261 participants and an analysis was conducted using the system of Structural Equation Modelings (SEM). The results revealed that investment in training, knowledge level and skills of the employee was positively connected to bank performance at less than $1 \%$ and a $5 \%$ level of significance. But, the employee's educational level does not substantially affect bank output in this analysis. The focus field is the study of the human capital investments of the Human Resources Division at Janata Bank Limited. It investigates different aspects of the Janata Bank's facilities as well as the problems and prospects. Thus, this study can be a policy dialog for the managers, owners, decision-makers, and academicians.
\end{abstract}

Keywords: Human capital, Human capital investment, Bank performance, Janata Bank Limited, SEM. 


\section{Introduction}

One of the most important factors contributing to economic growth of a nation is human resources. Various factors, including product and process growth, healthy enterprise niches, financial capital exposure and economies of scale, have been traditionally the basis of strategic strategies of companies. But financial assets in an entrepreneurial environment such as today no longer offer lasting competitive advantages marked by market fragmentation, increased demand and the rapid speed of technological change [1]. An organization's contribution to the human resources will significantly benefit the business and the people employed inside the group. "It helps to be more successful in employee growth and makes the organization perform healthier [2]." Every organisation's human capital offers an overview of personal history incorporated into the collective capacity of the company to reveal the optimal approach from its distinct workers [3]. Competence and skills are essential to an organization's future success and security. It is widely recognized that a person's schooling and preparation over a period of his or her working life improves his or her willingness and capacity to work, solve challenges, and conduct creativity. "The global market is increasingly facing shifts in technologies, processes, and products. Generally, most companies make improvements in their workers' preparation because they think it can contribute to better efficiency and deliver success $[4,5]$."

The hypothetical framework for this study is Human Capital Theory. The theory of human capital is also expanded to include its direct and indirect impact on bank performance. "The investment theory of human capital suggests that people with more or more human capital carry out tasks [6]." Human Capital (HC) is an inventory of the skills and abilities of human beings. In particular, human capital includes entrepreneurs' unique insights, skills, cognitive features, and capacities [7]. It also includes the accumulated attributes and habits that can influence productivity in positive or negative ways [6]. HC is a dynamic resource, important for understanding the differences in the recognition and utilization of opportunities [8]. Tan, Plowman [9] explored the correlation between Singapore Stock Exchange firms' intellectual resources and financial performance. In this context, as measures of financial success, they used equity, earnings per share, annual return, and used value-added intellectual coefficients (VAIC) for calculating intellectual capital. The findings of their analysis illustrate the positive relationship between the intellectual capital and the company's potential success. They also concluded that intellectual capital's growth rate has a positive relationship to firm performance. As HC is an intellectual capital aspect, we hypothesize that human capital influences firm performance. Thus, based on this it can also be said that investment in human capital may have 
an impact on bank performance. Also, Ozkan, Cakan [10] looked at the connection between VAIC and the market value-to-book relationship in the Turkish banking sector. The fallouts of their investigation show that the dependent variable (Price to Book Ratio) has significant correlations with the independent variable (VAIC) with its three components (one was HC).

Across this report, we analyze the effect of the investment in human capital (IHC) on the performance of Janata Bank Limited (JBL) in Bangladesh. More explicitly, we respond to a substantial question: Does investment in human capital affect bank performance? A lower amount of primary data-based studies are available about human capital and company performance in the developing countries like Bangladesh. Some secondary data-based studies have been found in the literature who covered the intellectual capital but didn't mention the investment in HC. No direct relationship between investment in human capital and performance has not been found in the existing literature of Bangladeshi banking industry. Thus, to fill up this gap, we researched with a structural relationship covering the investment in human capital with performance considering the primary data-based study. Another unique concept in that study is to choose different branches of a single bank as the sample for this study. In Bangladesh, for the banking industry, no research is found considering the single bank with multiple branches covering this structured relationship. That's why this study has deemed to cover several branches of Janata Bank Limited in Bangladesh. Thus, we conduct this study through a rational investigation with a structured questionnaire and examine whether a positive relationship exists between investment in human capital and the performance of bank. We consider four constructs to proxy human capital investment. They are the investment in training of employee (TR), education level of the employee (ED), knowledge level of employee (KN), and skills of employees(SK). We employ the structural equation modeling (SEM) technique through path analysis to test the hypotheses and find that training of the employees, knowledge level of the employees, and skills of the employees are significant to enhance the performance of Janata Bank Limited (JBL). Further, we discover that education doesn't significantly affect the performance of JBL.

This research adds to established literature in at least three respects: firstly, the structural review of this study shows that a positive effect of investing in human capital on bank performance exists within a single organizational body. Secondly, due to the geographical pattern, Bangladesh is a suitable place to prepare the employee as human capital for any organization. This study proves that within the same banking partition, human capital investment improves 
banks' profitability. Thirdly, the Structural Equation Modeling, which offers not only an evaluation of the model fit as to the reliability and validity of each tested construct, but also the overall model, was employed for the methodological concern. Thus, the findings of this study are derived from the best-fitted model.

\section{Literature review and hypothesis development}

\subsection{Investment in Human Capital and Bank Performance}

This section is related to studies examining the connection between human capital investment and bank performance. In today's review, the idea of human capital received enormous attention. Bontis, Dragonetti [3] describe human capital as the human trait within the company; the combined intellect, abilities and experience that characterizes the organization. "Intellectual capital defined knowledge, experience, expertise, and related soft assets instead of their financial and physical hard capital [11]. It involves three components: Customer Capital, Structural Capital (SC), and Human Capital (HC) [11, 12]." Human capital is a blend of knowledge, abilities, expertise and learning [13]. Human beings are a high-value commodity and in the sense of intellectual capital, human capital is known as a primary component. The idea of human capital was fully established in the 1960s with the introduction of human capital theory $[14,15]$. The term "Human Capital" is a key factor for increasing the productivity of company assets and employees and retaining a competitive edge leading to improved financial performance [16]. This explanation illustrates the need of human capital to aid in financial performance of a business.

Mamun [17] conducted an investigation into the important relationship between human resources reporting and company size, form and profitability based upon secondary data from 55 Bangladeshi companies. His study found only $25 \%$, on average, of all human resources things reported by the businesses, and found important positive ties to the company's size, categories and profitability. In a three-year longitudinal analysis of 32 leading Bangladeshi manufacturing and service companies, Khan [18] noted that due to government regulations in Bangladesh the coverage of HC reports increased. Their secondary data-based analysis found that banking firms report more HC than other firms. Absar, Orazalin [19] carried out a secondary data-based study and found that Bangladeshi banks disclosed more HC information than Kazakhastan. "Armstrong [20] describes HC as any human skill whose value can be enhanced by suitable creation expenditure, be it inherent or acquired characteristic." "Davenport [21] states that human capital is the inviolable asset given to its employers by 
employees. He made additional comments: people possess inherent talents, conduct and personal vitality, and these fundamental elements constitute the human resources."

The definition of bank performance can vary in this connection. However, clear explanations of bank performance could be proposed in the context of improving human capital. "There are two facets of business success: financial and non-financial. Financial metrics include the percentage of revenue, income and resources used and return on assets (ROA) [22, 23].” The modern paradigm of performance management stresses the integration of financial and nonfinancial behavior. Some of the flaws in traditional intervention are resolved by tangling financial metrics such as customer satisfaction, organizational performance, income, innovation, etc. Non-financial practices by themselves are problematic. "The HC of a business is an essential source of sustainable competitive advantage [24], and therefore, investment in workforce human resources will improve efficiency and financial performance for employees [25]." The organization's human capital is increased by helping individuals develop knowledge, skills, and competency. "Employees are well equipped to work and the business in general gains [26]." "The resource-based theory notes that the success of companies depends on how management structures their businesses around important, rare, inimitable and unsubstituted resources. [27]." Human resources follow these requirements, and the corporation can then look after and preserve resources with such assets as a result of enhancing organizational efficiency [28]. It is mentionable that there remains a gap in the findings of the existing literature to cover the relationship between investment in human capital and performance. No one directly mention the links of investment in human capital with performance. So, we postulate our main hypothesis based on this limited literature as follows:

H1: There is a positive relationship between investment in human capital and bank performance.

\subsection{Training of Human Resources and Bank Performance}

Investments in human capital are cost-effective, so that overall projected returns (cash flow) are greater than the costs of investment. It is not accurate to determine the effectiveness of the learning operation solely based on its costs. This decision will usually be more costly than reducing the cost of inadequate learning. Therefore, the opposite approach to assessing the efficacy of training's monitoring gain (contribution) could be preferred, which may represent positive measures of improvement. 
"Any activity which improves the quality of the worker (productivity) is investment in capital [29]." And preparation is an essential part of the investment in human resources. This refers to the knowledge and training needed and obtained by someone to improve their ability to conduct economic value activities. "The word training refers to the acquisition of know-how, knowledge and skills derived from technological or practical skills and information related to specific functional competences [30]." Besides the necessary preparation required for a trade, job or occupation, labor market analysts recognize today the need to seek practice beyond initial qualifications: to maintain, develop and improve skills over the whole of their working life. This form of training can be called career progression for people in other branches and occupations. Fraser, Storey [31] present and apply a panel-data methodology based-on secondary data for estimating the impact of the scheme of training of employee on firm growth, and find a positive relationship covering some small firms. Garcia [32] links training policies and business performance, Aragón, Barba [33] connects training tools and business results. Glaveli and Karassavidou [34] mentions the relationship between training and organization needs to be unlocked (studied), and they constructed the relationship with job satisfaction based-on primary data analysis. Clearly, Due to lack of enough studies in connecting the relationship between training of the employees and performance of firm, this study is designed. Thus, first, we examine whether the training of human resources has a positive relationship with human capital effectiveness (bank performance) to support our main hypothesis, and we hypothesized the following hypothesis:

Hla: There is a positive relationship between the training of employees and bank performance.

\subsection{The education level of Human Resource and Bank Performance}

It is also necessary to invest in corporate education to ensure that professional workers who build a competitive edge are hired and retained in businesses. Investment in an effective system for distributing corporate benefits is an important solution for recruiting and retaining employees as well as for developing high-quality staff teams [35]. "Drábek, Lorincová [36] suggest a diagram about the business benefits to increase employee morale and interest." Therefore, the efficacy, fairness and suitability of market advantages need to be routinely measured and checked to assist in determining employee success and hence the rewarding scheme.

A study by Bontis and Fitz-enz [13] noticed the impact of the management of human capital, in which the link was formed between managing human capital and the economic outcomes. 
In the financial services companies in their report, a total of 25 companies were selected. The research analyzed the efficacy of human capital through four metrics: revenue factor, cost factor, income factor and the HC ROI (Human Capital Return on Investment). Nguyen, Hagendorff [37] conducted a secondary-data based study, and find that executive characteristic generates wealth for shareholders in the US banking sector but this study can be an evidence for the developed country. Grima, Seychell [38] ran a primary data-based study and connect the level of education with derivative mishandling, Baldacchino, Caruana [39] find through their primary data analysis that education level can lead good working relationship, and Mahboud [40] states a secondary-data based study for the quality of financial reporting. The fundamental aspects of any company are to generate more profits per employee. Human capital has a direct influence on intellectual properties, which would generate higher financial performance per employee. As there is a scarce of literature covering directly the training and firm performance, we consider the level of education of employees with firm performance. We hypothesized the following hypothesis:

H1b: There is a positive relationship between the education level of employees and bank performance.

\subsection{Knowledge of Human Resource and Bank Performance}

In any case the absence of workforce training is correlated with a low degree of productivity [41]. A greater share of human resources is related to higher productivity and higher wages

[42]. Training is also related to business longevity [43] and increased corporate and economic development propensity [44]. Furthermore, Doucouliagos [45] has recognized human capital as a tool to improve workers and increase their engagement, as well as to generate $R \& D$ investment and to gradually open the door to a new sensibilities for the economy and society at large. "The Oxford English Dictionary defines a person's skills and abilities through activities and education, theoretical and/or practical understanding of a person; (ii) what is known in a particular field or as a whole; facts and information; or (iii) the knowledge or familiarity of a concept or situation encountered." Different cognitive mechanisms are used to process information: interpretation, comprehension, expression, connection and perception. The word knowledge often means an assured understanding of a subject, with the capacity, where necessary, to use it for a specific purpose. The knowledge and performance of the workers are related to many studies (see, for example, Marimuthu, Arokiasamy [46]) but no link has been developed with firm performance. To cover this gap, therefore, third, we examine 
whether the knowledge of human resource has a positive relationship with bank performance to support the main hypothesis, and we hypothesized the following hypothesis:

H1c: There is a positive relationship between knowledge of employees and bank performance.

\subsection{Skills of Human Resource and Bank Performance}

An industry is recognized for its skills restructuring and diversification due to skilled technological and coordinated changes [47]. The intention is to see to what degree the banks support elastic wage agreements and then corrode administrative and uniform wage laws. Certainly, workers with a specific set of skills must be able to meet the demands of modern employment [48]. When businesses are encouraged to invest money in their management, the singularity of human capital increases. It reduces the risks and builds on the potential for production. Therefore, individuals need to develop their abilities and skills to be successful within their organizations. A knowledge is an ability that is often mastered to produce predetermined outcomes with a minimal amount of time, resources or both. Usually, ability to assess the magnitude of the potential displayed and used requires certain outside factors and circumstances. The first move in understanding the economic value of skills should be based on the theory of $\mathrm{HC}$ of Becker [6]. Becker emphasizes the return to general skills that are useful in any organization and unique skills which a single company values. Employees require a variety of qualifications, in particular domain skills, to contribute to the success and efficiency of the business in order to compete [47]. A lower amount of studies have been found connecting the skills and performance of firm $[49,50]$. Considering this, fourth, we examine whether the skills of the human resource can predict bank performance to support the main hypothesis.

H1d: There is a positive relationship between the skills of employees and bank performance.

\section{The Methodology and Variables of the study}

\subsection{The Methodology of the Study}

This research analyzes the primary data for human capital effects using structural equation models (SEM). The statistical analysis of this study has been equipped using R software. Due to the applicability of an integral model for research, SEM is chosen as a statistical analysis technique. SEM offers not only an evaluation of the models fit for the reliability and validity of each evaluated build, but also the overall model.

This research considers the convenience sampling method. The data was composed through a 
questionnaire survey that is designed on the 7 Point Likert Scale. We collect data from 283 respondents. But all didn't respond properly. Some questions remained blank. Finally, we find a 261 questionnaire fully filled up. That's why we used the 261 observations in this study. The study uses the R programming software, particularly the "lavaan package" for SEM, and the EndNote X9 for managing the references. "The lava package is designed to deliver a commercial package for latent variable modelling to applied researchers, teachers, statisticians, and students. A broad range of multivariate statistical models can be calculated using lavaan including path analysis, confirmatory factor factor analysis, structural equation modelling and growth curve models. Structural equation modeling ( SEM) by R programming is an extensive field used in the social and behavioral sciences by many applied researchers [51].”

For the structural equation model ( SEM) the measuring model is a prerequisite, which relates the measures with their respective latent variables. In order to confirm the validity and reliability of the measuring pattern, we present the theoretical context and statistical analysis (see Analysis section). Figure 1 shows the conceptual model.

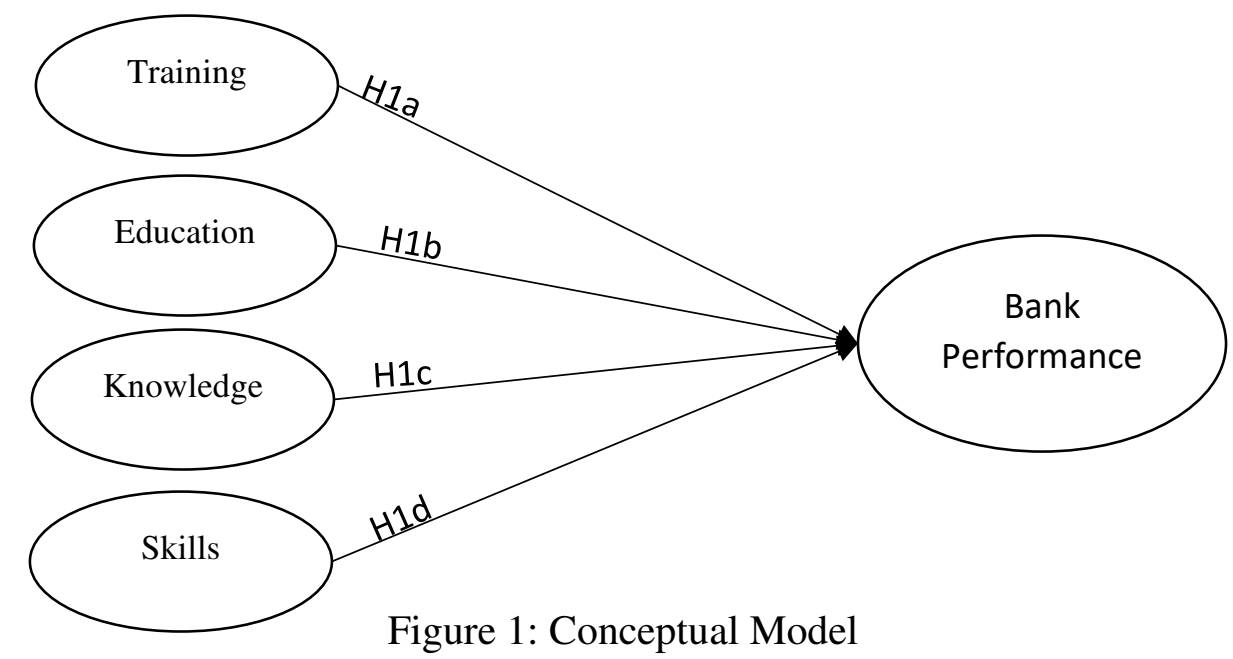

\subsection{Operationalization of latent variables}

According to Fig. 1, the conceptual pattern consists of five multifaceted latent variables which can not be calculated by a single observed variable. Thus, each of the latent variables in the conceptual model is determined by multifaceted objects.

The four exogenous variables are training (TR), education (ED), knowledge (KN), and skills (SK). The only one endogenous variable is the bank performance (BP). We take both exogenous and endogenous variables [52] to inspect the effect behind them.

For the first exogenous variable training, we use seven items mentioning "Individual and team training and development, nursing training and development, career development, work design, 
and performance appraisal, effectiveness, efficiency [52, 53]." These items are measured on a scale ranging from $1=$ strongly disagree to $7=$ strongly agree. The exact wording of the training and development object is, for example, "In your opinion, the individual employee training and development programs are effective."

"Consistent with Katou [53] and [52], for the second exogenous variable that is the education construct, we use four items referring to educational qualification. These items are measured on a scale ranging from $1=$ strongly disagree to $7=$ strongly agree, enquiring respondents to make up the academic level of the employee." For instance, the particular expression for educational qualification is, "You think that the education level of the employee is good."

"For the development of the knowledge construct, which is the third exogenous variable, we follow the construct development design of training above because cognate knowledge is a function of experience and training [53]. Thus, these items are measured on a scale ranging from 1 = strongly disagree to 7 = strongly agree." For example, the exact wording for the knowledge item is, "In your opinion, the employee training and development programs on employee knowledge are effective."

"To develop the skills construct, which is the fourth exogenous variable, we use five items relating to competency, management-employee cooperation, and employee cooperation. This is because although competencies are assumed to be fundamental for any improvement in performance [54], they are not enough for improving organizational performance unless employees are cooperated and motivated [55]. These items are measured on a scale ranging from 1 = very bad to 7 = very good, questioning respondents to report human capital performance (skills) over the previous three years to minimize random variations and anomalies in the data." For example, for the competence item the exact expression is, "How would you rate employee competences over the past 3 years?"

The endogenous variable (dependent) is the output of the bank that measures the baseline results for HRM [56]. "The success of the enterprise (both financial and non-financial) is typically demonstrated by things such as efficiency, that is if the bank achieves its goals; efficiency, that is, if the bank requires as little resources as possible to accomplish its goals; development, that is, if the bank is developing in its dimensions to meet future prospects and challenges; satisfaction of all applicants - owners and investors, customers, society, other companies, and organization adherents, innovation for products and processes; and quality, $\%$ of products and services of high eminence." These items were listed on a scale of $1=$ very bad 
to 7 very good, which asked respondents to report the performance of banks over the last three years to eliminate random fluctuations and anomalies in the results. The exact formulation of the effective item is, for example, "How would you rate the overall bank's effectiveness and efficiency to meet the objectives over the past three years?"

\section{Analysis and findings}

\subsection{Demographic profile of the respondents}

"Kline [57] proposes at least 100 observations for SEM and 200 observations for accurate estimate that are surely reached by our sample of 261." The demographic profile of the respondents is illustrated briefly in Table 1 . The sample is roughly proportional to $51 \%$ of men and $49 \%$ of women. The sample is equitable. As far as education is concerned, 40 percent of participants have a bachelor's degree and 44 percent have a master's program, which means that more than 80 percent have more technical skills. With regard to the age group, $26 \%$ and $36.78 \%$ are older than 22 years, so they operate at their fluent age and we have good and dependable answers.

Table 1: Demographic profile of the respondents

\begin{tabular}{|c|c|c|c|}
\hline \multirow{4}{*}{ Education } & Classification & $\begin{array}{l}\text { No. of } \\
\text { Respondents }\end{array}$ & Percentage (\%) \\
\hline \multirow{4}{*}{ Age Group } & Masters & 114 & $44 \%$ \\
\cline { 2 - 4 } & Honors & 104 & $40 \%$ \\
\cline { 2 - 4 } & HSC & 22 & $8 \%$ \\
\cline { 2 - 4 } & SSC & 15 & $6 \%$ \\
\cline { 2 - 4 } & JSC & 6 & $2 \%$ \\
\cline { 2 - 4 } & Total & $\mathbf{2 6 1}$ & $\mathbf{1 0 0 \%}$ \\
\cline { 2 - 4 } & $17-22$ years & 53 & $20.31 \%$ \\
\cline { 2 - 4 } & $22-27$ years & 68 & $26 \%$ \\
\cline { 2 - 4 } & $27-32$ years & 96 & $36.78 \%$ \\
\cline { 2 - 4 } & $32-$ above & 44 & $\mathbf{1 0 0 \%}$ \\
\hline \multirow{4}{*}{ Gender } & Total & $\mathbf{2 6 1}$ & $51 \%$ \\
\cline { 2 - 4 } & Male & 132 & $49 \%$ \\
\cline { 2 - 4 } & Female & 127 & $\mathbf{1 0 0 \%}$ \\
\cline { 2 - 4 } & Total & $\mathbf{2 6 1}$ & \\
\hline
\end{tabular}

\subsection{Check for Normality}

We evaluate the normality of the measuring elements using both multi-variant and univariate normality tests before moving to the measuring model, namely the CFA model. The normality of the data is important because the CFA (and SEM) estimation method depends on data normality. Mardia test (p-value < 0.05) rejects a zero multivariate normality hypothesis, and likewise Shapiro-Wilk test (all p-values $<0.05$ ) rejects the null univariate normality hypothetic. 
Therefore, the measuring model is calculated instead of an estimator of the maximum probability (MLR), also known as the Satorra Bentler rescaling process [51].

\subsection{Reliability and validity}

Measurement data was obtained by means of an independently recorded questionnaire. Each object is calculated on a Likert scale of 7 points, with '7' strongly in agreement and '1' strong disagreement. The exploratory factor analysis ( EFA) of the 23 items confirmed using confirmatory factor analysis ( CFA) after the third item of the training build is dropped (see table 2). The standardized factor loadings of the CFA model are shown in the right column of Table 2, each statistically significant $(\mathrm{p}$-value $<0.001)$. These are representative of the underlying latent construct of the items. This shows that the model is convergent in validity [58]. Table 2 also presents Cronbach's alpha [59] omposite Reliability (CR) of each factor. Alpha and CR values from all variables in Cronbach are greater than 0.70 recommended according to Hair, Anderson [60]. The measurement model's reliability is therefore specified.

Table 2: Measurement items and their reliability

\begin{tabular}{|c|c|}
\hline Constructs and their respective items & $\begin{array}{c}\text { Factor } \\
\text { loadings }\end{array}$ \\
\hline Bank Performance (BP, Alpha: 0.93, CR: 0.93) & - \\
\hline $\begin{array}{l}\text { 1. "How would you rate the overall bank's effectiveness and efficiency to meet the } \\
\text { objectives over the past three years?" }\end{array}$ & 0.897 \\
\hline 2. "How would you rate the total satisfaction of all participants over the past three years?" & 0.953 \\
\hline $\begin{array}{l}\text { 3. "How would you rate the overall development, innovation, and quality of products, } \\
\text { processes, and services of the bank over the past three years?" }\end{array}$ & 0.873 \\
\hline Training (TR, Alpha: 0.84, CR: 0.84$)$ & - \\
\hline $\begin{array}{l}\text { 1. "In your opinion, individual employee training and development programs are } \\
\text { effective." }\end{array}$ & 0.699 \\
\hline $\begin{array}{l}\text { 2. "In your opinion, the team of employee training and development programs are } \\
\text { effective." }\end{array}$ & 0.691 \\
\hline $\begin{array}{l}\text { 3. "In your opinion, the monitoring of employee training and development programs are } \\
\text { effective." }\end{array}$ & Dropped \\
\hline 4. "In your opinion, the career development programs by training are effective." & 0.654 \\
\hline 5. "In your opinion, employee training and development programs are sufficient." & 0.692 \\
\hline 6. "In your opinion, your work design programs are effective." & 0.683 \\
\hline 7. "You think that the training of employees can lead to increase bank performance." & 0.659 \\
\hline \multicolumn{2}{|l|}{ Education (ED, Alpha: 0.84, CR: 0.84) } \\
\hline 1. "You think that the education level of the employee is good." & 0.756 \\
\hline $\begin{array}{l}\text { 2. "You think that the effectiveness of a bank can partly be linked to the educational } \\
\text { qualification of the employee." }\end{array}$ & 0.741 \\
\hline $\begin{array}{l}\text { 3. "You think that the financial performance of a bank can be connected to the educational } \\
\text { level of the employee." }\end{array}$ & 0.794 \\
\hline 4. "You think that the educational level of the employee is important." & 0.748 \\
\hline Knowledge (KN, Alpha: 0.92, CR: 0.92) & - \\
\hline $\begin{array}{l}\text { 1. "In your opinion, the employee training and development programs on employee } \\
\text { knowledge are effective?" }\end{array}$ & 0.905 \\
\hline 2. "In your opinion, the work design programs on employee knowledge is effective." & 0.98 \\
\hline $\begin{array}{l}\text { 3. "You think that the financial performance of a bank can be promoted by the knowledge } \\
\text { level of the employee." }\end{array}$ & 0.781 \\
\hline
\end{tabular}




\begin{tabular}{|l|l|}
\hline $\begin{array}{l}\text { 4. "You think that the effectiveness of a bank can be linked by the knowledge level of the } \\
\text { employee." }\end{array}$ & 0.787 \\
\hline Skills (SK, Alpha: $\mathbf{0 . 8 2 , C R : ~} \mathbf{0 . 8 2})$ & - \\
\hline 1. "How would you rate employee competencies over the past three years?" & 0.712 \\
\hline $\begin{array}{l}\text { 2. "How would you rate cooperation among employees in general over the past three } \\
\text { years?" }\end{array}$ & 0.743 \\
\hline $\begin{array}{l}\text { 3. "How would you rate cooperation between management and employees in general over } \\
\text { the past three years?" }\end{array}$ & 0.625 \\
\hline $\begin{array}{l}\text { 4. "How would you connect the skills of the employees and the bank's effectiveness over } \\
\text { the past three years?" }\end{array}$ & 0.715 \\
\hline $\begin{array}{l}\text { 5. "How would you join the skills of the employees and bank performance over the past } \\
\text { three years?" }\end{array}$ & 0.653 \\
\hline
\end{tabular}

Note: "CFA model fit: $\chi 2(220)=464.843$, CFI $=0.94$, TLI $=0.93$, RMSEA $=0.05$, SRMR $=0.06$; Alpha represents value of Cronbach's alpha, and CR represents composite reliability."

Table 3: Divergent validity analysis.

\begin{tabular}{|c|c|c|c|c|c|}
\hline & TR & ED & KN & SK & CP \\
\hline TR & 1 & & & & \\
\hline ED & 0.421 & 1 & & & \\
\hline KN & 0.241 & 0.166 & 1 & & \\
\hline SK & 0.209 & 0.363 & 0.157 & 1 & \\
\hline BP & 0.308 & 0.299 & 0.197 & 0.315 & 1 \\
\hline AVE & $\mathbf{0 . 4 5 6}$ & $\mathbf{0 . 5 7 8}$ & $\mathbf{0 . 7 5 2}$ & $\mathbf{0 . 4 7 8}$ & $\mathbf{0 . 8 2 4}$ \\
\hline
\end{tabular}

Note: "Values in the matrix represent squared correlations among latent variables. A higher AVE value than the column-wise squared correlations indicates divergent validity."

"Divergent or discriminant validity (DV) confirms whether constructs connected to each other. A proof of this is that all latent variables are placed in a matrix and compared to their average variance (AVE), as seen in Table 3. According to Hair, Anderson [60], in order to validate the $\mathrm{DV}$, the squared-correlations below diagonal should be less than AVE of the individual latent variable. Table 3 confirms latent variable DV, while border line thresholds for tangible AVE and squared correlation covers the bus. Thus, we confirm the DV of the latent variables.

\subsection{Correlations among the latent variables.}

"The measurement model suits well, as the Comparative Fit Index (CFI) and the Tucker-Lewis Index (TLI) show up above the recommended level by 0.90 , (see precisely below table 2), and Root Mean Square Error Approximation (RMSEA) and Standardized Root Mean Square Residual (SRMR) below the cut-off value of 0.08 [60]." The correlation matrix is presented in Table 4 as the measuring model is now defined.

Table 4: Correlations among latent variables.

\begin{tabular}{|c|c|c|c|c|c|}
\hline & TR & ED & KN & SK & CP \\
\hline TR & 1 & & & & \\
\hline ED & 0.649 & 1 & & & \\
\hline KN & 0.49 & 0.407 & 1 & & \\
\hline SK & 0.457 & 0.603 & 0.396 & 1 & \\
\hline BP & 0.555 & 0.547 & 0.444 & 0.562 & 1 \\
\hline
\end{tabular}


Note that "the correlation matrix represents correlation among the latent variables based on extracted factor values through confirmatory factor analysis (CFA)."

\subsection{Common method bias}

General method bias refers to analytical problems of calculating errors. For example, a common calculated scale (for example, a 7 point Likert scale) could lead to common method bias for all survey questions. "Podsakoff, MacKenzie [61] offers a few mathematical solutions for normal process biases, each with advantages and disadvantages. We are using Harman's single factor test, the most commonly used in this analysis. We carry out an untouched study of exploratory factor using the latent charging of 23 products. Just $35 \%$ (well below the suggested cutout) reflect the average shift explained by the individual factor." Therefore, common method prejudice in this study is not a concern.

\subsection{Structural Equation Model}

"Since the measurement model is set out in the previous section, we continue to look at relations between latent variables in the structural model. Again, we are using the SEM MLR calculation, as suggested by Rosseel [51], for non-normal data." Figure 2 indicates the path analysis of SEM. "It is very difficult to achieve equivalent theoretical and observed structural model of 5 percent statistics in complex SEM studies with more than 12 measurement objects, such as this study [60]. In these cases, the ratio of chi-square and DF should be lower than three [62], which is evident in the estimated SEM model $(417.482 / 199=2.0)$, indicating a good model fit." Additional criteria for model fit indices are satisfied. The CFI and TLI are higher than 0.90, the RMSEA and SRMR lower than 0.08. The SEM estimates are therefore valid. 


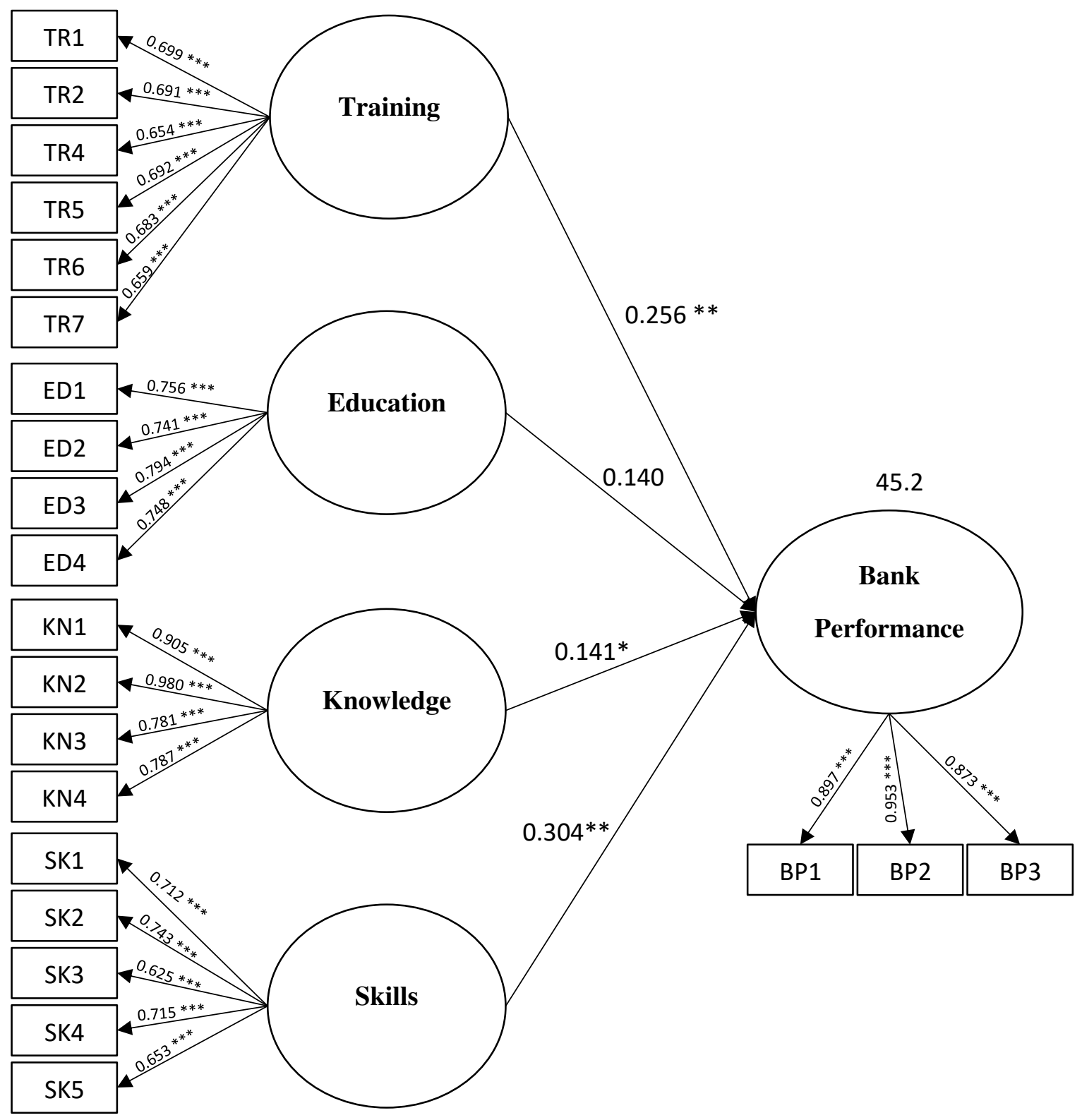

Figure 2: The structural equation model.

“*** $\mathrm{p}<0.001,{ }^{* *} \mathrm{p}<0.01,{ }^{*} \mathrm{p}<0.05$, SEM model fit: $\chi 2(199)=417.482, \mathrm{CFI}=0.94$, TLI $=$ 0.93, RMSEA $=0.05$, SRMR $=0.06$. R-square $=45.2 \% . "$

Table 5: Summary of hypothesis testing.

\begin{tabular}{|l|l|l|}
\hline Hypothesis & Standardized coefficient & Remark \\
\hline H1a: Training $\rightarrow$ Bank performance & $0.26(0.13) * *$ & Supported \\
\hline H1b: Education $\rightarrow$ Bank performance & $0.14(0.11)$ & Not supported \\
\hline H1c: Knowledge $\rightarrow$ Bank performance & $0.14(0.06) *$ & Supported \\
\hline H1d: Skills $\rightarrow$ Bank performance & $0.30(0.10) * *$ & Supported \\
\hline
\end{tabular}

"Standard error in parenthesis. ${ }^{* * *} \mathrm{p}<0.001,{ }^{* *} \mathrm{p}<0.01, * \mathrm{p}<0.05 . "$

Based on the SEM model in Figure 2, we present a summary of hypothesis testing in Table 5.

The four sub-hypotheses to proxy the main hypothesis relate to the association of training, 
education level, knowledge level, and skills with bank performance. H1b is not supported among the four, suggesting that education level of the employee is not connected with bank performance in the framework of Janata Bank Limited in Bangladesh. "H1a, H1c, and H1d are supported, implying a positive association between training and bank performance, knowledge level of employee and bank performance, and skills of the employee and bank performance." Thus, these suggest that the more the significance of training of the human resource, the higher is the bank performance, the better the knowledge of the human resource, the higher is the bank performance, and the higher the skills of the human resource, the higher is the bank performance. Overall, as our three hypotheses out of four have been supported, thus, it can be concluded that "The investment in human capital has a significant positive impact on bank performance", which means our main hypothesis (H1) is supported.

\section{Conclusion, Limitation, and Scope for further study}

This research aims to contribute understanding the relationship between performance and investment in human capital in Bangladesh's perspective, particularly in the banking sector. We target one (single) bank but multiple branches and found that there is a positive connection between performance and human capital investment. A single bank operates its banking activities through various branches employing unique rules and regulations for all branches. So, it is important to test why performance differs among the branches. The findings exposed that factors of human capital investment; first, training; second, knowledge level, and third skills have a significant positive impact on bank performance. This findings generated from this study are complementary to the findings of Absar, Orazalin [19], Fraser, Storey [31], and Garcia [32] in the case of training of employees. We find that the education level of the employees is not significant to affect the bank performance in developing countries, and is not consistent with the finding of Nguyen, Hagendorff [37] who found the significant relationship in the developed country's example. Further, the finding regarding knowledge level of the employees can be complementary to the findings of Marimuthu, Arokiasamy [46]. Finally, we

find that more skilled employees generate higher bank performance, and this finding is consistent with the findings of Caputo, Cillo [49] and Siepel, Camerani [50]. Across our study, the education level factor is not significant. Higher investment in training factor augments bank performance. More skilled employees contribute to higher performance for banks. It implies that investment in the skilled factor should be increased. In the case of the education level of the employees, this study implies that the level of education doesn't influence the performance 
of banks. The findings also exposed that the better the knowledge level, the higher the bank performance.

The significance of this study states in the fact that if the policymakers want substantial financial and non-financial results from their banking industry, it shows the importance of training, knowledge, and skills to bank shareholders. To attain high efficiency, they must constantly train and retrain their workers to learn cognitive and state-of-the-art skills to provide services that, in turn, will result in high bank performance and competitive advantage. Most small-scale companies do not prioritize training of workers in which strategy for firm success and efficiency resides. But, the education level of the employees can be ignored if others remain cream of the crop. Therefore, this study can be a policy dialog for the bank regulators, policymakers, academicians and practitionars.

Although this study helps to explain the causes of human capital investment in performance determination, there are some limitations. First, it is limited (e.g., Janata Bank Limited) to one context. Secondly, the data were obtained using a convenient sampling process, with the results of this analysis being subject to generalization restrictions. Third, there are limited numbers of respondents. For a broad sample for the analysis, future research is needed. Fourthly, in various demographic classes, such as male, female, master, honour, ages, etc., the concept of human capital investment can be distinct. Human capital is a lively issue; repeatedly it should be assessed. It is recommended that the future study use a mixed study (This survey utilizes primary data) to gain the relative impact of investment in human capital and bank results.

\section{Declarations}

\section{Availability of data and materials}

Data and material are available unpon request.

\section{Competing interests}

This research declars no interest to compete.

\section{Funding}

No funding is available for this research.

\section{Authors' contributions}

In this research both authors contributed equally.

\section{Acknowledgements}

We are thankful to the colleagues who assit us in this research. 


\section{Reference}

1. Perez, J.R. and P.O. de Pablos, (2003) Knowledge management and organizational competitiveness: a framework for human capital analysis. Journal of Knowledge management. 7(3): 82-91.

2. Awan, M.A.S. and N. Sarfraz, (2013) The Impact of human capital on Company performance and the mediating effect of employee's satisfaction. IOSR Journal of Business Management. 8(2): 76-82.

3. Bontis, N., et al., (1999) The knowledge toolbox:: A review of the tools available to measure and manage intangible resources. European management journal. 17(4): 391-402.

4. Alliger, G.M., et al., (1997) A meta-analysis of the relations among training criteria. Personnel psychology. 50(2): 341-358.

5. Kozlowski, S.W., et al., (2000) A multilevel approach to training effectiveness: Enhancing horizontal and vertical transfer. Jossey-Bass Publisher.

6. Becker, G.S., (2009) Human capital: A theoretical and empirical analysis, with special reference to education. Chicago University of Chicago press.

7. Venkataraman, S., (1997) The distinctive domain of entrepreneurship research. Seminal ideas for the next twenty-five years of advances. 21: 5-20.

8. Shane, S. and S. Venkataraman, (2000) The promise of entrepreneurship as a field of research. Academy of management review. 25(1): 217-226.

9. Tan, H.P., D. Plowman, and P. Hancock, (2007) Intellectual capital and financial returns of companies. Journal of Intellectual capital. 8(8): 76-95.

10. Ozkan, N., S. Cakan, and M. Kayacan, (2017) Intellectual capital and financial performance: A study of the Turkish Banking Sector. Borsa Istanbul Review. 17(3): 190-198.

11. Moon, Y.J. and H.G. Kym, (2006) A model for the value of intellectual capital. Canadian Journal of Administrative Sciences/Revue Canadienne des Sciences de l'Administration. 23(3): 253269.

12. Bollen, L., P. Vergauwen, and S. Schnieders, (2005) Linking intellectual capital and intellectual property to company performance. Management Decision. 43(9): 1161-1185.

13. Bontis, N. and J. Fitz-enz, (2002) Intellectual capital ROI: a causal map of human capital antecedents and consequents. Journal of Intellectual capital. 3(3): 223-247.

14. Schultz, T.W., (1961) Investment in human capital. The American economic review. 51(1): 117.

15. Hendricks, J.A., (1976) The impact of human resource accounting information on stock investment decisions: An empirical study. The accounting review. 51(2): 292-305.

16. Schultz, T.W., (1993) The economic importance of human capital in modernization. Education economics. 1(1): 13-19.

17. Mamun, S.A.A., (2009) Human resource accounting (HRA) disclosure of Bangladeshicompanies and its association with corporate characteristics. 6(1): 35-43.

18. Khan, R., (2010) Human capital disclosure practices of top Bangladeshi companies. Journal of Human Resource Costing Accounting. 14(4): 329-349.

19. Absar, M.M.N., N. Orazalin, and M. Mahmood, (2012) Human capital reporting in emerging economies: a comparative study on the banking sectors of Bangladesh and Kazakhstan. Journal of Academy of Business Economics. 12(3): 28-35.

20. Armstrong, M., (2011) Armstrong's handbook of strategic human resource management. Philadelphia Kogan Page Publishers.

21. Davenport, T.O., (1999) Human capital: What it is and why people invest it. Jossey-Bass Inc Pub.

22. Selvarajan, T., et al., (2007) The role of human capital philosophy in promoting firm innovativeness and performance: Test of a causal model. The International Journal of Human Resource Management. 18(8): 1456-1470. 
23. Hsu, I.-C., et al., (2007) Toward a model of organizational human capital development: Preliminary evidence from Taiwan. Asia Pacific Business Review. 13(2): 251-275.

24. Hitt, M.A., R.D. Ireland, and J.S. Harrison, (2001) Mergers and acquisitions: A value creating or value destroying strategy. The Blackwell handbook of strategic management. Cornwall: Blackwell Publishing.

25. Pfeffer, J. and P. Jeffrey, (1998) The human equation: Building profits by putting people first. Harvard Business Press.

26. Cunningham, S., (2002) From cultural to creative industries: theory, industry and policy implications. Media International Australia incorporating Culture Policy. 102(1): 54-65.

27. Barney, J., (1991) Firm resources and sustained competitive advantage. Journal of management. 17(1): 99-120.

28. Crook, T.R., et al., (2008) Strategic resources and performance: a meta-analysis. Strategic management journal. 29(11): 1141-1154.

29. Lee, C.H. and N.T. Bruvold, (2003) Creating value for employees: Investment in employee development. International Journal of Human Resource Management. 14: 981-1000.

30. Guest, D.E., (2002) Human resource management, corporate performance and employee wellbeing: Building the worker into HRM. Journal of Industrial Relations. 44(3): 335-358.

31. Fraser, S., et al., (2002) The Relationship between Training and Small Business Performance: An Analysis of the Barclays Bank Small Firms Training Loans Scheme. Environment and Planning C: Government and Policy. 20(2): 211-233.

32. Garcia, M.U., (2005) Training and business performance: the Spanish case. International Journal of Human Resource Management. 16(9): 1691.

33. Aragón, A., J. Barba, and R. Sauz, (2003) Effects of training on business results. International Journal of Human Resource Management. 14(6): 956.

34. Glaveli, N. and E. Karassavidou, (2011) Exploring a possible route through which training affects organizational performance: the case of a Greek bank. The International Journal of Human Resource Management. 22(14): 2892-2923.

35. Hitka, M., et al., (2015) Corporate culture as a tool for competitiveness improvement. Procedia Economics Finance. 34: 27-34.

36. Drábek, J., S. Lorincová, and J. Javorčíková, (2017) Investing in Human Capital as a Key Factor for the Development of Enterprises. Issues of Human Resource Management. 1(1): 113-136.

37. Nguyen, D.D., J. Hagendorff, and A. Eshraghi, (2015) Which executive characteristics create value in banking? Evidence from appointment announcements. Corporate Governance: An International Review. 23(2): 112-128.

38. Grima, S., S. Seychell, and F. Bezzina, (2017) Investigating factors predicting derivative mishandling: a sociological perspective. European Research Studies Journal. 20(4A): 3-17.

39. Baldacchino, P.J., et al., (2017) Selected Behavioural Factors in Client-Initiated Auditor Changes: The Client-Auditor Perspectives. European Research Studies. 20(2): 16.

40. Mahboud, R., (2017) Main Determinants of Financial Reporting Quality in the Lebanese Banking Sector. European Research Studies 20(4B): 706-726.

41. Green, F., (1993) The determinants of training of male and female employees in Britain. Oxford Bulletin of Economics Statistics. 55(1): 103-122.

42. Mincer, J., (1997) The production of human capital and the life cycle of earnings: Variations on a theme. Journal of labor economics. 15(1, Part 2): S26-S47.

43. Bates, T., (1990) Entrepreneur human capital inputs and small business longevity. The review of Economics Statistics. 72(4): 551-559.

44. Goetz, S.J. and D. Hu, (1996) Economic growth and human capital accumulation: Simultaneity and expanded convergence tests. Economics Letters. 51(3): 355-362.

45. Doucouliagos, C., (1997) The aggregate demand for labour in Australia: a meta-analysis. Australian Economic Papers. 36(69): 224-242. 
46. Marimuthu, M., L. Arokiasamy, and M. Ismail, (2009) Human capital development and its impact on firm performance: Evidence from developmental economics. The Journal of International Social Research. 2(8): 265-272.

47. Suleman, F., (2012) The impact of skills and performance on earnings: evidence from retail bankers in Portugal. The International Journal of Human Resource Management. 23(11): 2205-2220.

48. Pillay, H., (1998) Cognitive skills required in contemporary workplaces. Studies in Continuing Education. 20(1): 71-81.

49. Caputo, F., et al., (2019) Innovating through digital revolution. The role of Soft Skills and Big Data in increasing firm performance. Management Decision. 57(8): 2032-2051.

50. Siepel, J., R. Camerani, and M. Masucci, (2019) Skills combinations and firm performance. Small Business Economics. 19: 1-23.

51. Rosseel, Y., (2012) Lavaan: An R package for structural equation modeling and more. Version 0.5-12 (BETA). Journal of statistical software. 48(2): 1-36.

52. Ukenna, S., et al., (2010) Effect of investment in human capital development on organisational performance: empirical examination of the perception of small business owners in Nigeria. European Journal of Economics, Finance Administrative Sciences. 10(26): 93-107.

53. Katou, A.A., (2009) The impact of human resource development on organisational performance: Test of a causal model. Journal of Behavioral Applied Management. 10(3): 335.

54. Hardré, P.L., (2003) The effects of instructional training on university teaching assistants. Performance Improvement Quarterly. 16(4): 23-39.

55. Perez Lopez, S., J.M. Montes Peon, and C.J. Vazquez Ordas, (2005) Human resource practices, organizational learning and business performance. Human Resource Development International. 8(2): 147-164.

56. Wang, G.G., Z. Dou, and N. Li, (2002) A systems approach to measuring return on investment for HRD interventions. Human Resource Development Quarterly. 13(2): 203-224.

57. Kline, R.B., (2015) Principles and practice of structural equation modeling. Guilford publications.

58. Anderson, J.C. and D.W. Gerbing, (1988) Structural equation modeling in practice: A review and recommended two-step approach. Psychological bulletin. 103(3): 411.

59. Cronbach, L.J.J.p., (1951) Coefficient alpha and the internal structure of tests. psychometrika. 16(3): 297-334.

60. Hair, J.F., et al., (2010) Multivariate data analysis: A global perspective. Vol. 7. London: Pearson Education.

61. Podsakoff, P.M., et al., (2003) Common method biases in behavioral research: a critical review of the literature and recommended remedies. Journal of applied psychology. 88(5): 879-903.

62. Bollen, K.A. and J.S. Long, (1992) Tests for structural equation models: introduction. Sociological Methods Research. 21(2): 123-131. 
Figures

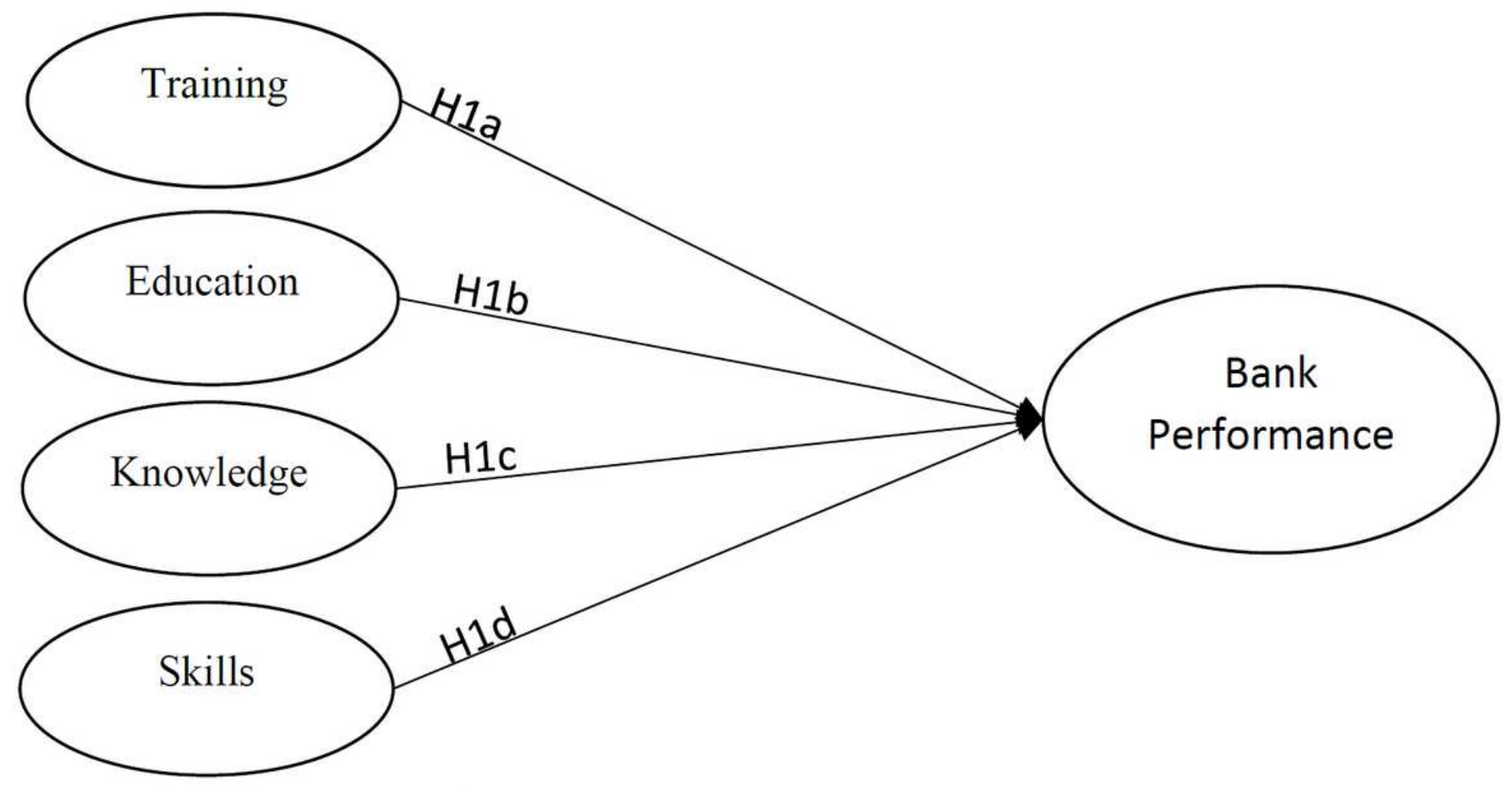

Figure 1

Conceptual Model 


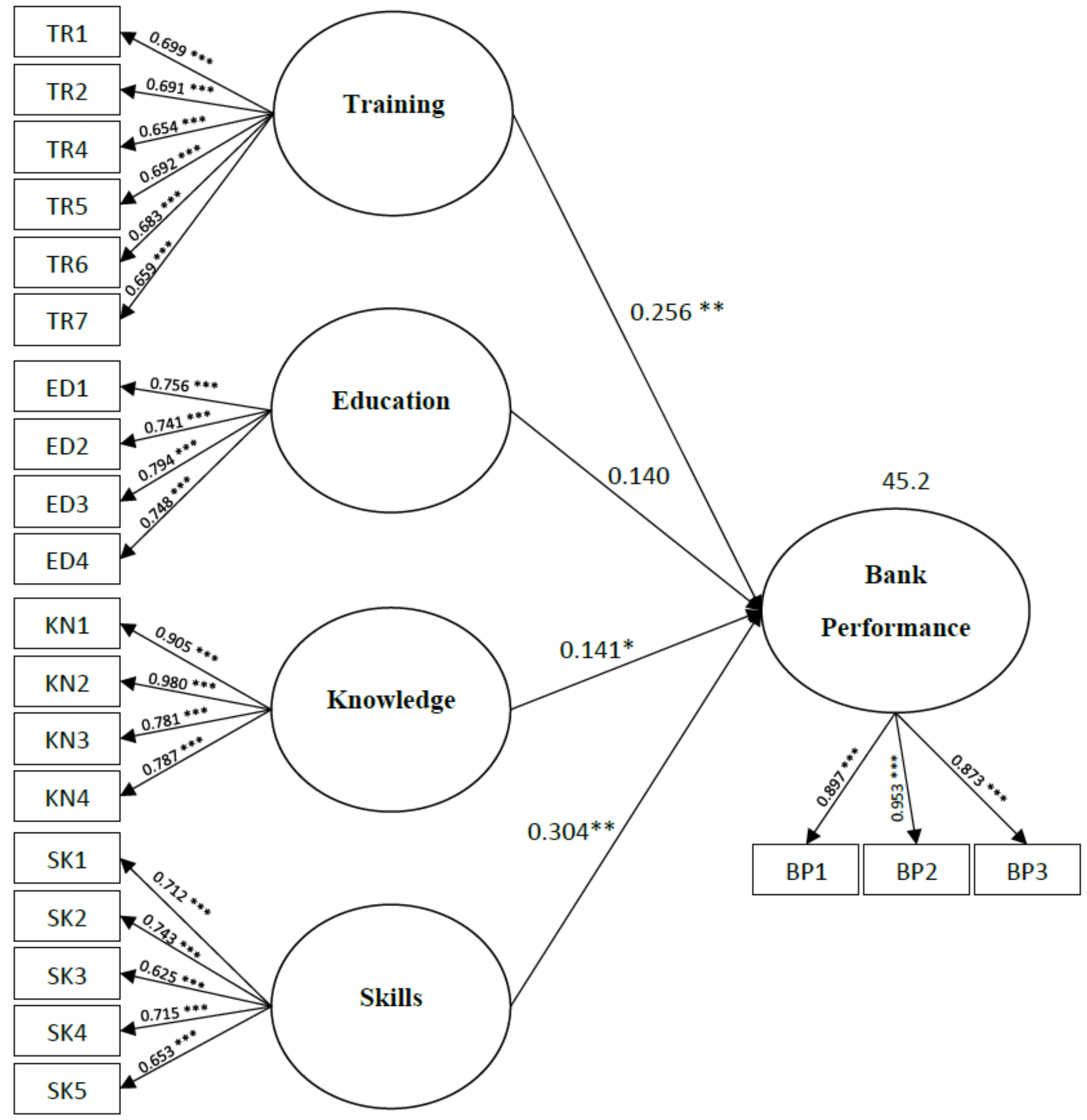

Figure 2

The structural equation model. " $\star \star \star x p<0.001, \star \star p<<0.01$, ${ }^{\star} p<0.05$, SEM model fit: $\chi 2(199)=417.482$, CFI $=0.94, \mathrm{TLI}=0.93, \mathrm{RMSEA}=0.05, \mathrm{SRMR}=0.06$. R-square $=45.2 \% . "$ 